ISSN: 2224-0616

Int. J. Agril. Res. Innov. \& Tech. 8 (1): 55-61, J une, 2018

Available online at http:// www.ijarit.webs.com

\title{
IMPACTS OF THREE PESTICIDES ON ARTHROPOD BIODIVERSITY IN BRINJ AL AGRO-ECOSYSTEM
}

\author{
S. Akter ${ }^{*}$, M.Z. Alam², M.S. Rana ${ }^{3}$ and H.B. Saif ${ }^{4}$ \\ Received 19 March 2018, Revised 13 June 2018, Accepted 26 June 2018, Published online 30 June 2018
}

\begin{abstract}
A field study was conducted to find out the impact of three selected pesticides on arthropod biodiversity in brinjal agro-ecosystem during 2011-2012 at Bangabandhu Sheikh Mujibur Rahman Agricultural University (BSMRAU). Twenty-six arthropod species were observed through visual searching method out of which 18 were insect pest species (from 14 families under 8 orders) and 8 were natural enemies (from 8 families under 6 families). Twenty one species of surface dwelling arthropods were caught in pitfall traps method, 12 of them were insect pest species (from 11 families under 8 orders) and 9 were natural enemies (from 9 families under 5 orders). Formicidae was the most abundant family among them. Bacillus thuringiensis (Bt) and Tracer 45SC (Spinosad) were less harmful to arthropod pest species as well as natural enemies in the brinjal agro-ecosystem. Proclaim 5SG reduced the overall abundance of arthropod species. Bacillus thuringiensis (Bt) and Tracer 45SC were relatively safe for natural enemies and therefore would be fit well into integrated pest management (IPM) against BSFB of brinjal crop.
\end{abstract}

Keywords: Arthropod Biodiversity, Brinjal Shoot and Fruit Borer, Integrated Pest Management (IPM), Diversity index, Equitability

\footnotetext{
${ }^{1}$ Scientific Officer, Soil Survey Interpretation Section, Soil Resource Development Institute, Dhaka- 1215, Bangladesh.

${ }^{2}$ Department of Entomology, Bangabandhu Sheikh Mujibur Rahman Agricultural University, Gazipur-1706, Bangladesh.

${ }^{3}$ Scientific Officer, Plant Breeding Division, Bangladesh Institute of Nuclear Agriculture, Barisal-8211, Bangladesh.

${ }^{4}$ Scientific Officer, Planning and Evaluation Wing, Bangladesh Agriculture Research Institute, Gazipur- 1701, Bangladesh.

*Corresponding author's email: sharmin.srdi@gmail.com (S. Akter)
}

\section{Introduction}

Brinjal, Solanum melongena $\mathrm{L}$. is one of the most important and popular vegetable crops grown in Bangladesh as well as in South and South-East Asia. Bangladesh produced 0.238 million tons of brinjal from an area of 28631.509 hectares with an average yield $8.00 \mathrm{t} \mathrm{ha}^{-1}$, which is approximately 15 and $13 \%$ of the total vegetable area and production of our country, respectively (Anonymous, 2011).

One of the main constrains of brinjal production is its vulnerability to pest attack. In brinjal field in addition to Brinjal Shoot and Fruit Borer, Leucinodes orbonalis Guenee (Lepidoptera: Pyralidae) as the major pest, various arthropod species both pests and natural enemies prevail from seedling to harvesting stage. EL-Shafie (2001) observed 28 species of insect pests of 7 different orders from the brinjal ecosystem, while Nayar et al. (1995) reported 53 species of insect pests of brinjal. Many arthropod natural enemies of those obnoxious pests also exist in the same ecosystem (FAO, 2003).

In general, common insecticides are not specific and they frequently kill natural enemy populations and may causes upset and resurgence of other pest population (Pedigo, 2002). In addition, development of insect biotypes resistant to the commonly used insecticides is not uncommon (Pedigo, 2002). Many researchers reported that insecticides killed other non-target arthropods, caused serious ecological imbalance and affected arthropods biodiversity (Alam et al., 2006, Navntoft et al., 2006, Filho et al., 2004, Prijno et al., 2004, Rodriaguez et al., 2003).

The present studies were, therefore, conducted to know effect of different selected prospective insecticides on arthropod biodiversity including natural enemies for judging their suitability as eco-friendly component in the IPM package of BSFB.

\section{Materials and Methods}

The experiment was conducted during November 2011 to April 2012 in RCB design with four replications. Details of the insecticides used with their doses are given in Table 1. The whole field was divided into 4 blocks of equal size having space of 2 meters between blocks and 1 meter between plots. Each block was subdivided into 4 equal plots including one control plot. The unit plot size was $3 \mathrm{~m} \times 2 \mathrm{~m}$ accommodating 10 pits per 
plot. The distance between rows was $1 \mathrm{~m}$ and that of plants was $60 \mathrm{~cm}$. A total of 160 seedlings were planted in 16 plots @ 10 seedlings plot-1.

The first application of insecticides was made after $8^{\text {th }}$ week of transplantation and subsequent applications in each treatment were made at twelve days intervals. Four liters of spray volumes were required to spray four plots at each spraying before fruiting stage while subsequent applications during fruiting required five liters each to ensure cover spray. Urea, TSP, MP and cow dung were applied in the field @ $250 \mathrm{~kg}, 150$ $\mathrm{kg}, 125 \mathrm{~kg}$ and $15 \mathrm{~kg} \mathrm{ha}^{-1}$, respectively as recommended by Rashid (1993). Other recommended agronomic practices were also followed.

Table 1. List of pesticides and their groups, trade names, chemical names and concentrations used in various treatments.

\begin{tabular}{|c|c|c|c|c|}
\hline Class & Common name & Trade name & Chemical name & Concentration \\
\hline Microbial & Bacillus & 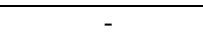 & Bacillus thuringiensis (Bt) & $0.4 \mathrm{~g} /$ liter \\
\hline Pesticide & thuringiensis & & & \\
\hline $\begin{array}{l}\text { Microbial } \\
\text { Pesticide }\end{array}$ & Spinosad & Tracer 45 SC & * Spinosad: Spinosyn A + Spinosyn D & $0.4 \mathrm{ml} /$ liter \\
\hline Biopesticide & $\begin{array}{l}\text { Emamectin } \\
\text { benzoate }\end{array}$ & Proclaim 5 SG & $\begin{array}{l}\text { 4"-epi-methylamino-4"deoxyavermectin } \\
\text { B1 benzoate }\end{array}$ & $1 \mathrm{~g} /$ liter \\
\hline
\end{tabular}

* 2-((6-deoxy-2, 3, 4-tri-O-methyl-a-Lmannopyranosyl) oxy)-13-(((5-dimethylamino) tetrahydro-6-methyl-2Hpyran-2-yl) oxy)-9-ethyl- 2,3,3a,5a,5b,6,9,10,11,12,13,14,16a,16 b-tetradecahydro-14-methyl-1H-asindaceno (3,2-d)oxacyclododecin-7,15-dione 2-((6-deoxy-2,3,4-tri-O-methyl-a-Lmannopyranosyl) oxy)-13-((5dimethylamino) tetrahydro-6-methyl-2H-pyran-2-yl)oxy)-9-ethyl-,3,3a,5a,5b,6,9,10,11, 12,13,14,16a,16 btetradecahydro-4, 14-dimethyl - $1 \mathrm{H}$-asindaceno(3,2-d)oxacyclododecin-7,15-dione.

\section{Data collection}

The number of species was the simplest measure of diversity. However, for limitation in species identification, concept was restricted to order and family level. The counting of individual was performed by using visual searching, sweeping net and pitfall trap method. The normal seasonal fluctuations and the population dynamics of arthropods were recorded from pesticides free plots of brinjal grown away from the pesticides treated plots, while for pesticide affected population the data on arthropods were collected from the pesticides treated plots.

\section{Visual searching method}

Arthropods species considering sessile, agile, adult, nymphs and larvae of flying insects on brinjal plants were counted from a random sample of 5 plants taken from each plot. Ten leaves were chosen randomly on each plant, four from the bottom (older leaves), two from the middle and four from the top (younger leaves). The lower surface of the leaf was thoroughly examined for the presence of insects. Counting was done before 08:30 $\mathrm{hr}$ (Bangladesh local time) to avoid the excessive mobility of the adult insects after this time, but the migration of the fast moving and mobile adults from one plot to the other could not be totally avoided. The data were pooled over the season's average was combined to provide an overall average density plot ${ }^{-1}$. The population density of each insect is expressed as number of individuals per 10 leaves of the plant. Individuals were counted from five branches selected randomly from 5 plants of each plot at weekly interval.

\section{Sweeping net method}

This method was used for counting insects on brinjal plants to know the abundance pattern of insects in the present study. Five times return sweeping was done in each plot to make a composite sample by a sweeping net at 15 days intervals. Each sample was examined separately without killing the insects and released them in the same plot immediately after counting. The individuals of each sample were counted by family.

\section{Pitfall trap method}

The pitfall trap method was used for the species that roam in the soil surface.Small plastic pots having $10 \mathrm{~cm}$ diameter and $18 \mathrm{~cm}$ deep were used as pitfall traps. Three traps were placed in soil in each of the plots and the mouth of the pot was kept at ground level, so as not to obstruct insect movement. Each pot was then half filled with water and detergent as trapping fluid. After 24 hours of setting traps, the trapped arthropods were emptied with a sieve and funnel into small plastic bottles filled to the half with $70 \%$ alcohol. The samples were labeled and stored until sorting, counting and finally were identified. Traps were set at 15 days intervals throughout the cropping season and insects were collected and counted separately from each plot.

\section{Measurement of diversity index}

To assess the abundance pattern and the species richness in different insecticides treated plots, Simpson's diversity index was used (Simpson, 1949). 
Simpson's Index $(D)=\frac{1}{\sum_{i=1}^{g} P t^{2}}$

Where, ' $\mathrm{Pi}$ ' is the proportion of individual for the ' $i$ 'th insect family and ' $\mathrm{S}$ ' is the total number of insect family in the community (i.e. the richness). The value of index depends on both the richness and the evenness (equitability) with which individuals distributed among the families. Equitability was quantified by expressing Simpson's index, ' $\mathrm{D}$ ' as a proportion of the maximum possible value of $\mathrm{D}$.

$$
\begin{aligned}
& \text { Equitability, } \mathrm{E}={ }_{D_{\max }}^{D}=\sum_{\sum_{i=1}^{s} p_{i}}^{1} \times \frac{1}{S} \\
& {\left[\mathrm{D}_{\max }=\mathrm{S}\right]}
\end{aligned}
$$

\section{Statistical analysis}

Data were analyzed by MSTAT-C software for proper interpretation. The data recorded on different parameters were subjected to analysis of variance (ANOVA) and the means were separated by Duncan's Multiple Range Test (DMRT) at 1\% level of significance (Gomez and Gomez, 1984).

\section{Results and Discussion}

\section{Plant dwelling insect pests' species}

Total of 18 insect pests' species from 14 families (under 8 orders) were recorded through visual searching method from insecticides free plots (Table 2). Most of the insect pests' species belong to the order Homoptera, Hemiptera,Coleoptera and Lepidoptera. Among insect pests species the highest abundance (185.67) was recorded in the species jassid followed by mealy bug (99.69), white fly (67.00), epilachna beetle (12.00), green leaf hopper (7.00) and less abundance species were leaf beetle, aphid, BSFB, flea beetle, thrips, hooded hopper, leaf roller etc. The frequency of BSFB adult was very low in the field though it was major pest of brinjal in terms of damaged shoots and fruits. The number of BSFB was very few because its adult is nocturnal in habit and no trap was used to collect the adult during night.

\begin{tabular}{|c|c|c|c|c|c|}
\hline $\begin{array}{l}\text { Sl. } \\
\text { No }\end{array}$ & Order & Family & Common name & Scientific name & $\begin{array}{c}\text { Total } \\
\text { abundance }\end{array}$ \\
\hline 1. & Homoptera & Cicadillidae & J assid & Amrasca biguttula biguttula & 185.67 \\
\hline 2. & Homoptera & Cicadillidae & Green leaf hopper & Nephotettix bipuctatus Fab. & 7.00 \\
\hline 3. & Homoptera & Aleyrodidae & White fly & Bemicia tabaci (Genn.) & 67.00 \\
\hline 4. & Homoptera & Aphididae & Aphid & Aphis gossypii Glover & 3.33 \\
\hline 5. & Homoptera & Membracidae & Hodded hopper & Oxyrachis terandus Fab. & 0.35 \\
\hline 6. & Hemiptera & Pentatomidae & Green vegetable bug & Nezara viridula (L) & 0.67 \\
\hline 7. & Hemiptera & Pentatomidae & Pentatomid bug & Eocantheconafurcellata & 0.32 \\
\hline 8. & Hemiptera & Pseudococcidae & Mealy bug & Coccidohystrix insolitus & 99.69 \\
\hline 9. & Hemiptera & Coriedae & Rice bug & Leptocorisa acuta & 0.33 \\
\hline 10. & Coleoptera & Coccinellidae & Epilachna beetle & $\begin{array}{l}\text { Epilachna 28-punctata Fab } \\
\text { Epilachna 12-puctata }\end{array}$ & 12.00 \\
\hline 11. & Coleoptera & Coccinellidae & Leaf beetle & Monolepta signata $\mathrm{Ol}$. & 6.33 \\
\hline 12. & Coleoptera & Halticidae & Flea beetle & Phyllotreta sp. & 1.33 \\
\hline 13. & Lepidoptera & Noctuidae & Leaf roller & Antoba olevacea & 0.33 \\
\hline 14. & Orthoptera & Acrididae & $\begin{array}{l}\text { Short horned } \\
\text { grasshopper }\end{array}$ & Heiroglyphus banian Fab. & 0.67 \\
\hline 15. & Orthoptera & Tettigoniidae & $\begin{array}{l}\text { Long horned } \\
\text { grasshopper }\end{array}$ & Conocephlus longipennis & 0.33 \\
\hline 16. & Hymenoptera & Formicidae & Red ant & Solenopsis geminata & 1.00 \\
\hline 17. & Thysanoptera & Thripidae & Thrips & Thrips tabaci & 0.67 \\
\hline 18. & Lepidoptera & Pyralidae & BSFB & Leucinodes orbonalis Guen. & 1.67 \\
\hline
\end{tabular}

Table 2. Abundance of insect pest species in insecticides free plots through visual searching method.

Data are the average of 3 replications from 12 observations.

\section{Plant dwelling beneficial arthropod species}

Total of 8 beneficial arthropod species from 8 families (under order 6) were recorded through visual searching method from insecticides free plots (Table 3). Most of beneficial arthropods belong to the order Coleoptera, Hymenopera,
Diptera and Araneae. Among natural enemies the highest abundance (126.67) was recorded in the species black ant followed by spider (18.33), ladybird beetle (11.33) and other available natural enemies were carabid beetle, mirid bug, staphylinid beetle and syrphid fly etc. 
Table 3. Abundance of beneficial arthropod species in insecticides free plot through pitfall trap method during summer.

\begin{tabular}{cccclc}
\hline $\begin{array}{c}\text { Sl. } \\
\text { No }\end{array}$ & Order & Family & Common name & Scientific name & $\begin{array}{c}\text { Total } \\
\text { abundance }\end{array}$ \\
\hline 1. & Hemiptera & Miridae & Mirid bug & Cyrtorhinus lividipennis & 0.33 \\
2. & Coleoptera & Coccinellidae & Lady bird beelte & Micraspis crocera Muls. & 11.33 \\
3. & Coleoptera & Carabidae & Carabid beetle & Ophionea nigrofasciata & 0.33 \\
4. & Coleoptera & Staphylinidae & Staphylinid beetle & Paederus indica curt. & 0.33 \\
5. & Hymenoptera & Formicidae & Black ant & Camponotus compressus & 126.67 \\
6. & Araneae & Araneidae & Spider & Mecynogea lemniscata & 18.33 \\
7. & Odonata & Coenagrionidae & Damsel fly & Agriocnemis spp. & 1.67 \\
8. & Diptera & Syrphidae & Syrphid fly & Syrphus confractor & 0.33 \\
\hline
\end{tabular}

Data are the average of 3 replications from 12 observations.

\section{Surface dwelling insect pests' species}

Total of 12 insect pests' species from 11 families (under 8 order) were recorded as surface dwelling insect pests through pitfall trap method from untreated control plots. Most of the insect pests' species belong to the orders Homoptera, Coleoptera, Hemiptera, Orthoptera and Isoptera. Available pests' species were field cricket, termite, red ant, short horned grasshopper and leaf beetle etc. (Table 4).

Table 4. Abundance of insect pest species in insecticides free plot through pitfall trap method.

\begin{tabular}{|c|c|c|c|c|c|}
\hline $\begin{array}{l}\text { Sl. } \\
\text { No }\end{array}$ & Order & Family & Common name & Scientific name & $\begin{array}{c}\text { Total } \\
\text { abundance }\end{array}$ \\
\hline 1. & Homoptera & Cicadillidae & Green leaf hopper & Nephotettix bipuctatus Fab. & 1.00 \\
\hline 2. & Homoptera & Membracidae & Hodded hopper & Oxyrachis terandus Fab. & 0.33 \\
\hline 3. & Hemiptera & Coreidae & Rice bug & Leptocorisa acuta & 0.33 \\
\hline 4. & Coleoptera & Elateridae & Click beetle & Agriotes sp & 0.33 \\
\hline 5. & Coleoptera & Chrysomelidae & Leaf beetle & Monolepta signata Ol. & 0.33 \\
\hline 6. & Coleoptera & & Flea beetle & Phyllotreta sp. & 0.33 \\
\hline 7. & Orthoptera & Acrididae & $\begin{array}{l}\text { Short horned } \\
\text { grass hopper }\end{array}$ & Heiroglyphus banian Fab. & 1.00 \\
\hline 8. & Orthoptera & Gryllidae & Field cricket & Brachytrypes portentosus & 2.67 \\
\hline 9. & Hymenoptera & Formicidae & Red ant & Solenopsis geminata & 3.33 \\
\hline 10. & Thysanoptera & Thripidae & Thrips & Thrips tabaci & 0.33 \\
\hline 11. & Blattodea & Blattidae & Cockroach & Blata orientalis & 1.00 \\
\hline 12. & Isoptera & Termitidae & Termite & Microtermes obesi & 0.33 \\
\hline
\end{tabular}

Data are the average of 3 replications from 7 observations.

\section{Surface dwelling beneficial arthropod species}

Total of 9 beneficial arthropod species from 9 families (under 5 order) were recorded through pitfall trap method from insecticides free plots. Most of the beneficial arthropods belong to the order Coleoptera, Hymenoptera and Aranae (Table 5).

Table 5. Abundance of beneficial arthropod species in insecticides free plot through pitfall trap method.

\begin{tabular}{cccclc}
\hline $\begin{array}{c}\text { Sl. } \\
\text { No }\end{array}$ & Order & Family & Common name & Scientific name & $\begin{array}{c}\text { Total } \\
\text { abundance }\end{array}$ \\
\hline 1. & Coleoptera & Cicindelidae & Tiger beetle & Cicindela cancellata & 0.67 \\
2. & Coleoptera & Scarabaeidae & Scarabid & Scarabaeus sp & 0.67 \\
3. & Coleoptera & Staphylinidae & Staphylinid beetle & Paederus indica curt. & 0.67 \\
4. & Coleoptera & Carabidae & Carabid beetle & Ophionea nigrofasciata & 0.67 \\
5. & Dermaptera & Carcinophoridae & Ear wig & Euboralia stali & 1.00 \\
6. & Diptera & Asilidae & Robber fly & Allocotosia aurata & 0.33 \\
7. & Hymenoptera & Formicidae & Black ant & Camponotus compressus & 27.00 \\
8. & Hymenoptera & Apidae & Wild bee & Apis melefera & 0.33 \\
9. & Araneae & Araneidae & Spider & Mecynogea lemniscata & 41.67 \\
\hline
\end{tabular}

Data are the average of 3 replications from 7 observations.

In comparison of cumulative abundance, The present finding are more or less in beneficial arthropods' species were dominated conformity with the findings of El-Shafie (2001), over insect pests' species among the surface who reported that Coleoptera had occupied dwelling arthropods. Most abundant natural maximum of the plant dwelling predators and enemies were spider, black ant, ground beetle, Formicidae as the most frequently appear surface earwig, carabid beetle and staphylinid beetle etc. dwelling predators in brinjal agro-ecosysytem. 
The comparative effects of three selected prospective pesticides on plant dwelling arthropods through visual searching method is presented in the Table 6 . In summer the highest number of arthropods families (22) was recorded in untreated control plots followed by Tracer 45SC (20) and Bt (17), while it was the lowest in treatment Proclaim 5SG (16). The highest total number of arthropods (403.67) was recorded in the plots treated with Tracer 45SC (20) followed by 551.33 in the control plots. The lowest number

Table 6. Diversity of arthropods species in three selected prospective insecticides treated plots and a control plot of brinjal agro-ecosystem through visual searching method.

\begin{tabular}{lcccc}
\hline Treatments & No. Of families & Total abundance & Diversity index & Equitability \\
\hline Bacillus thuringiensis (Bt) & 17.00 & 384.67 & 3.61 & 0.21 \\
Tracer 45SC & 20.00 & 403.67 & 3.17 & 0.16 \\
Proclaim 5SG & 16.00 & 211.67 & 3.38 & 0.25 \\
Control & 22.00 & 551.33 & 4.61 & 0.21 \\
\hline
\end{tabular}

Data are the average of 3 replications from 12 observations.

In summer (Table 7) the highest number of natural enemy families (9) was recorded in Tracer 45SC treated plots followed by untreated control plots (8) and the lowest number of families (6) was recorded in Proclaim 5SG treated plots. The highest number of natural enemy abundance (163.33) was recorded in untreated control plots followed by Tracer 45SC (118.00) and Bt (104). The lowest number of natural enemy abundance 63.00 was recorded in the plots treated with Proclaim 5SG. The diversity index was the highest (2.36) in the plots treated with Proclaim 5SG and the lowest diversity index (1.58) was obtained

from the plot treated Tracer 45SC followed by untreated control (1.62) and Bt (1.72) and their diversity index increased with the increase of total abundance except Bt and Tracer 45SC.

The highest equitability 0.39 was recorded from the plots treated with Proclaim 5SG (0.39) which indicates less richness of natural enemy species of this treatment. On the other hand the lowest equitability was obtained from Tracer 45SC (0.18) followed by Bt (0.25), which indicates species richness of natural enemy of these treatments.

Table 7. Diversity of natural enemies in three selected prospective pesticides treated plots and a control plot of brinjal agro-ecosystem through visual searching method.

\begin{tabular}{lcccc}
\hline Treatments & No. Of families & Total abundance & Diversity index & Equitability \\
\hline Bacillus thuringiensis (Bt) & 7.00 & 104.00 & 1.72 & 0.25 \\
Tracer 45SC & 9.00 & 118.00 & 1.58 & 0.18 \\
Proclaim 5SG & 6.00 & 63.00 & 2.39 & 0.36 \\
Control & 8.00 & 163.33 & 1.62 & 0.20 \\
\hline
\end{tabular}

Data are the average of 3 replications from 12 observations.

From sweeping net method (Table 8), the highest number of arthropods families (24) was recorded in untreated control plots followed by Bt (23.00) and Tracer 45SC (22.00). The lowest number of families (12.00) was recorded in Proclaim 5SG. The highest number of arthropods (250.67) was recorded in the untreated control plots followed by Bt (193.67) and Tracer 45SC (177.00). The lowest number of arthropods 142.00 was recorded in the plots treated with Proclaim 5SG. The diversity index was the highest (6.32) in the plots treated with Bt followed by untreated control plot (5.86) though the total abundance of Bt was less than the total abundance of untreated control plot but it showed higher diversity index than the untreated control plots, which indicates more abundance of some families than the other treatments. The lowest diversity index was obtained from in the plots treated with Tracer 45SC (2.17) followed by Proclaim 5SG (3.06).

The highest equitability 0.27 was recorded in the plots treated with Bt followed by Proclaim 5SG (0.26) and untreated control (0.24), on the other hand the lowest equitability was obtained in Tracer 45SC (0.10), lower equitability indicates higher species richness of the treatment. 
Table 8. Diversity of arthropod species in three selected prospective pesticides treated plots and a control plot of brinjal agro-ecosystem through sweep net method.

\begin{tabular}{lcccc}
\hline Treatments & No. Of families & Total abundance & Diversity index & Equitability \\
\hline Bacillus thuringiensis(Bt) & 23.00 & 193.67 & 6.32 & 0.27 \\
Tracer 45SC & 22.00 & 177.00 & 2.15 & 0.10 \\
Proclaim 5SG & 12.00 & 142.00 & 3.06 & 0.26 \\
Control & 24.00 & 250.67 & 5.86 & 0.24 \\
\hline
\end{tabular}

Data are the average of 3 replications from 12 observations.

From sweeping net method (Table 9) the highest number of natural enemy families (10) were recorded in Bt and untreated control followed by Tracer 45SC (9). The lowest number of families (5) was recorded in Proclaim 5SG. The highest number of natural enemy abundance (117.67) was recorded in the untreated control plots followed by Bt (78.00) and Tracer 45SC (67.67). The lowest number of natural enemy abundance 49.00 was recorded in the plots treated with Proclaim 5SG.

The diversity index was the highest (3.84) in the plots treated with Bt followed by Tracer 45SC
(3.39) and untreated control plots (3.19). Higher diversity index indicates more abundance of some families of this treatment. The lowest diversity index (2.21) was obtained in the plots treated with Proclaim 5SG.

The highest equitability 0.44 was recorded in the plots treated with Proclaim 5SG followed by, 0.38 and 0.38 in the plots treated with Bt and Tracer 45SC, respectively. On the other hand, the lowest equitability was obtained from untreated control plots (0.32) which indicate species richness of natural enemy of this treatment.

Table 9. Diversity of natural enemies in three selected prospective pesticides treated plots and a control plot of brinjal agro-ecosystem through sweep net method.

\begin{tabular}{lcccc}
\hline Treatments & No. Of families & Total abundance & Diversity index & Equitability \\
\hline Bacillus thuringiensis(Bt) & 10.00 & 78.00 & 3.84 & 0.38 \\
Tracer 45SC & 9.00 & 67.67 & 3.39 & 0.38 \\
Proclaim 5SG & 5.00 & 49.00 & 2.21 & 0.44 \\
Control & 10.00 & 117.67 & 3.19 & 0.32 \\
\hline
\end{tabular}

Data are the average of 3 replications from 12 observations.

During summer in pitfall trap method (Table 10) the highest number of arthropods families (22) were recorded in untreated control plots followed by Bt (16) and Tracer 45SC (15). The lowest number of families (8) was recorded in the plots treated with Proclaim 5SG. The highest number of arthropods (101.00) was recorded in the plots treated with Proclaim 5SG followed by Bt (92.33) and Tracer 45SC (91.33). The lowest number of arthropods 88.67 was recorded in the untreated control plots.
The diversity index was the highest (3.77) in the plots treated with Proclaim 5SG followed by Bt (3.26) and untreated control plots (3.22). The diversity index was lowest (3.18) in the plots treated with Tracer 45SC. The highest equitability 0.47 was recorded from the plots treated with Proclaim 5SG, on the other hand the lowest equitability 0.15 was obtained in untreated control plots followed by Bt (0.20) and Tracer 45SC (0.21). Lower the equitability indicates higher the arthropods species richness of these treatments.

Table 10. Diversity of arthropod species in three selected prospective pesticides treated plots and a control plot of brinjal agro-ecosystem through Pitfall trap method.

\begin{tabular}{lcccc}
\hline Treatments & No. Of families & Total abundance & Diversity index & Equitability \\
\hline Bacillus thuringiensis(Bt) & 16.00 & 92.33 & 3.26 & 0.20 \\
Tracer 45SC & 15.00 & 91.33 & 3.18 & 0.21 \\
Proclaim 5SG & 8.00 & 101.00 & 3.77 & 0.47 \\
Control & 22.00 & 88.67 & 3.22 & 0.15 \\
\hline
\end{tabular}

Data are the average of 3 replications from 12 observations.

During summer in pitfall trap method (Table 11) the highest number of natural enemy families (12) were recorded in Tracer 45SC \& untreated control plots followed by 9.00 in the plots treated with $\mathrm{Bt}$, the lowest number of families (6) were recorded in the plots treated with Proclaim 5SG. The highest number of natural enemy abundance
(95.67) was recorded in the plots treated with Proclaim 5SG followed by Bt (83.00). The lowest number of natural enemy abundance 81.00 was recorded in the untreated control plots.

The diversity index was the highest (3.39) in the plots treated with Proclaim 5SG, on the other hand the lowest diversity index (2.56) was 
obtained in the plots treated with Tracer 45SC followed by Bt (2.66). The highest equitability 0.57 was recorded in the plots treated with Proclaim 5SG, on the other hand the lowest equitability 0.21 was obtained in the plots the treated with Tracer 45SC followed by untreated control plots (0.22). Lower equitability indicates higher species richness of natural enemies of these treatments.

Table 11. Diversity of natural enemies in three selected prospective pesticides treated plots and a control plot of brinjal agro-ecosystem through Pitfall trap method.

\begin{tabular}{lcccc}
\hline Treatments & No. Of families & Total abundance & Diversity index & Equitability \\
\hline Bacillus thuringiensis(Bt) & 9.00 & 83.00 & 2.66 & 0.30 \\
Tracer 45SC & 12.00 & 81.33 & 2.56 & 0.21 \\
Proclaim 5SG & 6.00 & 95.67 & 3.39 & 0.57 \\
Control & 12.00 & 81.00 & 2.69 & 0.22 \\
\hline
\end{tabular}

Data are the average of 3 replications from 12 observations.

\section{Conclusion}

From the study, it may be concluded that collected arthropods through visual searching, sweeping net and pitfall trap methods revealed that Bacillus thuringiensis (Bt) and Tracer 45SC (Spinosad) were less harmful to arthropod species and natural enemies in the brinjal agroecosystem and thus would be suitable for IPM program for successful management of BSFB. On the other hand, Proclaim 5SG (Emamectin benzoate) was more harmful to arthropod biodiversity.

\section{References}

Alam, S.N., Hossain, M.I., Rouf, F.M.A., Jhala, R.C., Patel, M.G., Nath, L.K., Sengupta, A., Baral, K., Shylesha, A.N., Satpathy, S., Shivalingaswamy, T.M., Cork, A. and Talekar, N.S. 2006. Control of eggplant shoot and fruit borer in South Asia. Technical Bulletin 36, AVRDC- The World Vegetable Center, Shanhua, Taiwan. 88 p.

Anonymous. 2011. www.en.wikipedia.org/wiki/ Bacillus thuringiensis.

El-Shafie, H.A.F. 2001. The use of neem products for sustainable management of Homopterous key pests on potato and eggplant in Sudan. Ph. D. Thesis, Institute of Phytopathology and Applied Zoology Experimental Station Justus Liebig University of Giessen, Germany. $165 \mathrm{p}$.

FAO. 2003. Inter country programme for integrated pest management in vegetables in south and South-East Asia. Eggplant integrated pest management: An ecological guide. $177 \mathrm{p}$.

Filho, M.M., Guedes, R.N.C., Della-Lucia, T.M.C., Michereff, M.F.F. and Cruz, I. 2004. Nontarget impact of chlorpyriphos on soil arthropods associated with no-tillage corn fields in Brazil. Int. J. Pest Manage. 50 (2): 91-99.

Gomez, K.A. and Gomez, A.A. 1984. Statistical procedures of agricultural research. $2^{\text {nd }}$ Edn. International Rice Research Institute, John Willey and Sons, Inc. Singapore. pp. 139240.

Navntoft, S., Esbjerg, P. and Riedel, W. 2006. Effects of reduced pesticide dosages on carabids (Coleoptera: Carabidae) in winter wheat. Agril. Forest Entomol. 8 (1): 57-62.

Nayar, K.K., Ananthakrishnan, T.N. and David, B.V. 1995. General and Applied Entomology. 11th edn. Tata MeGraw-Hill Publ. Co. Ltd. 4/12, Asaf Ali Road, New Delhi-110002. p. 557.

Pedigo, L.P. 2002. Entomology and Pest Management. $4^{\text {th }}$ Edition. Prentice Hall, Upper Saddle River, New Jersey. USA. p. 742 .

Prijno, D., Robinson, M., Rauf, A., Bjorksten, T. and Hoffmann, A.A. 2004. Toxicity of chemicals commonly used in Indonesian vegetable crops to Liriomyza huidobrensis populations and the Indonesian parasitoiods Hemiptarsenus varicornis, Opius sp. and Gronotoma micromorpha, as well as the Australian parasitoids Hemiptarsenus varicornis and Diglyphus isaea. J. Econ. Entomol. 97 (4): 1191-1197.

Rashid, M.M. 1993. Begun Paribarer Shabji. In: Shabji Biggan (in Bangla). First Edn. Bangla Academy, Dhaka, Bangladesh. 65 p.

Rodriaguez. E., Pena, A., Raya, A.J.S. and Compos, M. 2003. Evaluation of the effect on arthropod populations by using deltamethrin to control Phloeotribus scarabaeoides Bern (Coleoptera: Scolytidae) in olive orchards. Chemosphere. 52 (1): 127134.

Simpson, E.D. 1949. Measurement of diversity. Nature. 163: 688. 